\title{
Characteristics and experiences of Chios breed
}

\author{
N. P. ZERVAS, J. HATJIMINAOGLOU, A. GEORGOUDIS, J. G. BOYAZOGLU \\ Department of Animal Production, Faculty of Agriculture, \\ Aristotle University, 54006 Thessaloniki, Greece
}

\begin{abstract}
Discussed are the reproductive and productive characteristics of the dairy and prolific Chios sheep breed, originating from the homonymous Greek island. Besides the island, the breed is also raised in the Greek mainland, the westcoast of Turkey and in Cyprus. It is early maturing, with long reproductive reason and lambing period, extending from October to March. Inspite its high ovulation rate, repeatability estimates do not suggest the presence of fecundity genes. The average prolificacy ratio ranges between 1.80 and 2.0 , with triplets and quadruplets not uncommon. The average exploitable milk yield varies between 180 and $200 \mathrm{~kg}$, with occasionally reported productions of up to 400 and $500 \mathrm{~kg}$. Repeatabilities of prolificacy and milk production based on island data were found 0.15 and 0.40 , respectively. Heritability of milk yield from the island was 0.31 and 0.40 , respectively, for second and third lactations. Recent estimates from Cyprus report values of 0.30 and 0.39 for 90 -day milk and total milk yield, respectively. Other parameters and information on udder (mechanical milking), growth, and carcass characteristics as well as on crossbreeding trials are also reported. Some considerations are given with regard to potential and valorization of this highly productive sheep breed.
\end{abstract}

Index words: Chios, reproduction, early maturity, ovulation rate, milk yield, growth, carcass, crossbreeding

\section{Raising and testing of Chios sheep}

The highly productive Chios (C) sheep breed originates from the homonymous Greek island, of the Aegean sea, but must have been influenced by fat-tailed animals of Asian provenance. The contribution of foreign blood is also suggested by its finer wool and more uniform fleece than that of the Greek Zackel (19). Besides the original small insular nucleus, numbering at present about 2000 animals (21), purebreds and crossbreds found in the Greek mainland and some islands are estimated to approach 100000 head (12). C breed under Sakiz is found in the neighbouring western Turkish coastal area, numbering some 13000 head (37). Higher numbers reported by other Turkish authors might include purebreds and crossbreds as well (2). A sizeable population of 80000 purebreds and 115000 crossbreds occurs in Cyprus and a limited number, used primarily for upgrading 
purposes, is found in North African, Middle East and other Mediterranean countries (30).

The animals under study are medium to large in size, with long body and legs, suggestive of a pronounced dairy conformation. The tail is characterized as semi-fat and coneshaped. The males have long spiral horns. The udder is large but pendulous, often with extra teats. The wool is essentially coarse but more uniform and thinner than that of the Greek Zackel. The colouring is white, with some black or dark spots around the eyes, at the tip of the ears and nose and often around the belly and legs. In the island of Chios they are kept as stall-fed animals on a family basis ( $1-10$ head). Their feeding is based on poor grazing or on dry roughages and little grain when kept indoors, which coincides with pregnancy and parturition. In the mainland, the flock size is around $50-100$ head and the management is more intensive. In Turkey, conditions of Sakiz are similar to those of the Chios island, with small flocks of 2-4 animals kept by individual families. These animals are not milk recorded. There are two recorded flocks at the Boztepe Station and at the Aegean University Farm (37).

The significance and the possibilities of $\mathrm{C}$ were recognized a long time ago and as a consequence, a systematic scheme was started in 1953 by the Ministry of Agriculture, with 17 communities of the central part of the island joining the milk control programme. In this first phase, 652 individuals were ear-marked, registered at the regional service and tested monthly for milk yield. Ever since, the programme was extended to 39 communities and between 1975 and 1978 the controlled ewes reached the number of 3500 (21). Tested ewes with annual milk production below $100 \mathrm{~kg}$ were culled. Rams from good mothers owned by local producers (private studs) were leased for natural service of ewes for a fee. Pedigree information, phenotypic characteristics and production data were collected, recorded and filed by the Agricultural Service of Chios. Annual milk production was estimated as the yield measured after lambs weaning (commercialised), but not earlier than 61 days after parturition. Reports on the reproductive and productive traits of $\mathrm{C}$ have been occasionally presented by Greek experts. A more detailed quantitative analysis of over 4500 observations was carried out by the first author in 1965 (38).

Since 1977, the Halkidiki Agricultural Research Station (H. Station), near the village Agios Mamas, has been assigned the task to investigate the physiological and zootechnical aspects of C. The above programme, supported by AGRIMED and financed by European Communities and the Greek Ministry of Agriculture, aimed at establishing a sizeable closed flock, with new facilities and additional technical personnel to help the development of the research scheme (6). The animals are housed in large open-front buildings and kept in confinement, except during summer and restricted grazing periods. Feeding of ewes, lambs and rams is based mainly on alfalfa hay and concentrates and only secondarily on grazing. Grazing during winter and spring is limited to barley grass, natural vegetation and temporary light grazing on cereal and alfalfa fields. No hormonal treatments are regularly used for breeding purposes except in specific cases of physiology studies. Lactating ewes are milked by machine and the milk and butterfat is measured at 15-day intervals. The selection of lambs for breeding is based on parental records (mainly milk production and secondarily prolificacy) and on their growth rate. By 1983 the flock attained the size of about 500 head. Data were fed to the computer of the University of Thessaloniki Farm. Complementary to the main experimental objectives, a number of ad-hoc studies have been conducted to untangle specific problems, e.g.: physiology of reproduction, feed utilisation, mechanical milking and carcass quality.

\section{Quantitative characteristics}

\section{Reproduction}

$\mathrm{C}$ is early maturing and can be bred at $8-9$ 
months of age. Studies at the H. Station found the first estrus occurring between 243 and 290 days, with corresponding ewe-lamb weight of $37-43 \mathrm{~kg}$ (31). C ewes show a long reproductive season with a rather limited anestrous period occurring between December and March. Observations on 27 ewes disclosed that from September to March more than $80 \%$ of females showed at least one estrus per month (1). Under experimental conditions and the presence of rams, $60 \%$ of lactating ewes demonstrated estrus during 42-day suckling (31). Distribution of parturitions showed that at the H. Station (2991 cases) and in the Island (4707 cases) peak months were November with $40 \%$ and January with $42 \%$ lambings, respectively. It is also reported that some ewes may lamb two times during the same year. The average gestation length in 2131 cases was found to be $149.21 \pm 2.54$ days (31). Detailed research at the $\mathrm{H}$. Station on the ovulatory activity with laparoscopy and progesterone determination revealed that the average ovulation rate was $3.25 \pm 0.81$, and the repeatability 0.33 . The relatively low estimate of repeatability suggests that the high ovulation rate of the $\mathrm{C}$ ewes is not controlled by fecundity genes (1).

C demonstrates high prolificacy, significantly superior to that of mainland breeds. Average prolificacy in the Island during the periods $1957-62(38)$ and $1980-86(21)$, as well as in mainland units, was found to be approx. 1.80 , as shown in Table 1 , where is also given its breakdown by lactation. Prolificacy ratios and frequency of multiple births by litter size (LS) from H. Station data (6), are given in Tables 2 and 3, respectively. One can attribute the relatively higher prolificacy at the H. Station (1.8 to 2.2 ) mostly to improved environmental factors and secondarily to selection. Observations made in Turkey $(35,32,37)$ on Sakiz give prolificacy ratios varying between 1.98 and 2.27 , with $16 \%$ single, $54 \%$ twins, $19 \%$ triplets and $11 \%$ quadruplets and quintuplets. Work at Lebanon (4) reports prolificacy for the first lactation 1.76 and productivity (lambs weaned/ewes presented
Table 1. Prolificacy ratios (lambs born alive).

\begin{tabular}{lcccc}
\hline Lactation & \multicolumn{2}{c}{} & & $\begin{array}{c}\text { Mainland } \\
\text { units }\end{array}$ \\
\cline { 2 - 3 } \cline { 5 - 5 } & $1957-62$ & $1980-86$ & & 1984-1985 \\
\hline $1^{\text {st }}$ & 1.52 & 1.55 & & 1.54 \\
$2^{\text {nd }}$ & 1.69 & 1.73 & & 1.83 \\
$3^{\text {rd }}$ plus & 1.76 & 1.76 & & 1.83 \\
\hline Average & 1.76 & 1.75 & & 1.75 \\
Lambings & 5356 & 3705 & 890 \\
\hline
\end{tabular}

Table 2. Prolificacy ratios (Halkidiki Station).

\begin{tabular}{lrrrrr}
\hline $\begin{array}{l}\text { Lacta- } \\
\text { tion }\end{array}$ & $\begin{array}{r}\text { Lambings } \\
\text { alive }+ \\
\text { dead }\end{array}$ & $\begin{array}{r}\text { Prolif. } \\
\text { ratio }\end{array}$ & $\begin{array}{r}\text { Lambs } \\
\text { born } \\
\text { alive }\end{array}$ & $\begin{array}{c}\text { Prolif. } \\
\text { ratio }\end{array}$ \\
\hline $1^{\text {st }}$ & 885 & 1597 & 1.80 & 1511 & 1.71 \\
$2^{\text {nd }}$ & 573 & 1184 & 2.07 & 1105 & 1.93 \\
$3^{\text {rd }}$ & 316 & 691 & 2.19 & 638 & 2.02 \\
$4^{\text {th }}$ plus & 290 & 647 & 2.23 & 584 & 2.01 \\
\hline $\begin{array}{l}\text { Total or } \\
\text { average }\end{array}$ & 2064 & 4119 & 2.00 & 3838 & 1.86 \\
\hline
\end{tabular}

Table 3. Percentage litter size (Halkidiki Station).

\begin{tabular}{lrrr}
\hline $\begin{array}{l}\text { Litter size } \\
\text { per lambing }\end{array}$ & Lambings & $\%$ & $\begin{array}{r}\text { Total lambs } \\
\text { alive + dead }\end{array}$ \\
\hline Single & 641 & 31.1 & 641 \\
Twins & 924 & 44.8 & 1848 \\
Triplets & 388 & 18.8 & 1164 \\
Quadruplets & 94 & 4.6 & 376 \\
Quintuplets & 13 & 0.6 & 65 \\
Sextuplets & 4 & 0.2 & 24 \\
\hline Total & 2064 & 100.0 & 4118 \\
\hline
\end{tabular}

for service) 1.22. From 211 ewes in the Island, with a total of 736 parturitions and average LS 1.85 (lambs born alive), the repeatability of prolificacy was found to be $r=0.15$ (38). However, heritability estimates of LS at birth and at weaning based on 852 parturitions in two state farms in Cyprus were for lambs born, lambs born alive and lambs weaned $0.44 \pm 0.12,0.28 \pm 0.10$ and $0.20 \pm 10$, respectively (28). These estimates are much higher than others reported in the literature.

\section{Milk production}

$\mathrm{C}$ breed combines superior fertility and high 
Table 4. Annual milk production (post weaning), $\mathrm{Kg}$.

\begin{tabular}{|c|c|c|c|c|c|c|c|c|}
\hline \multirow[t]{2}{*}{ Lactation } & \multicolumn{2}{|c|}{$\begin{array}{c}1957-62 \\
\text { Island }\end{array}$} & \multicolumn{2}{|c|}{$\begin{array}{c}\text { 1979-83 } \\
\text { Island }\end{array}$} & \multicolumn{2}{|c|}{$\begin{array}{c}1977-86 \\
\text { H. Station }\end{array}$} & \multicolumn{2}{|c|}{$\begin{array}{c}1984-86 \\
\text { Units }\end{array}$} \\
\hline & $\mathrm{N}$ & & $\mathrm{N}$ & & $\mathrm{N}$ & & $\mathrm{N}$ & \\
\hline $1^{\mathrm{st}}$ & 461 & 128.9 & 377 & 165.5 & 886 & 174.7 & 256 & 137.9 \\
\hline $2^{\text {nd }}$ & 919 & 165.9 & 560 & 189.5 & 572 & 215.0 & 224 & 178.5 \\
\hline $3^{\text {rd }}$ plus & 3554 & 182.6 & 1635 & 204.6 & 606 & 218.4 & 433 & 178.7 \\
\hline Average & & 174.5 & & 195.6 & & 198.7 & & 167.2 \\
\hline Total & 4934 & & 2572 & & 2064 & & 913 & \\
\hline
\end{tabular}

milk yield (MY) (with a long lactation period). Depending on systems of raising and management conditions, the reported annual commercialised MY varies between 120 and $300 \mathrm{~kg}$. In Turkey, mean values of MY are reported to vary between 120 and $180 \mathrm{~kg}$, but under experimental conditions the average lactation yields were found between 188 and 259 $\mathrm{kg}$ (37). In Cyprus, 102 lactation records at the Agriculture Research Institute have given post weaning milk production $118.7 \mathrm{~kg}$ in 90 days and $195.1 \mathrm{~kg}$ in 193.5 days (27). From 1811 officially controlled ewes in Cyprus the average MY of the 90 first days was $128 \mathrm{~kg}$ (30).

In Greece summarised results of milk control from different sources are given in Table 4 $(38,21,8)$. On the average, the annual MY (commercialised) from adult lactations varies between 180 and $200 \mathrm{~kg}$, after a suckling period of $40-60$ days. The average post weaning lactation length varies between 150 and 200 days, depending on management conditions. Selected individuals can produce up to $500 \mathrm{~kg}$ of milk, as indicated in Table 5. Average maximum daily MY, as recorded in the Island, was found about 1800 to $2000 \mathrm{~g}$. At the H. Station the distribution of maximum daily production was found as follows: 1000$2000 \mathrm{~g}=63 \%, 2000-3000 \mathrm{~g}=28 \%$ and over $3000 \mathrm{~g}=2.5 \%$. Butterfat analysis at the $\mathrm{H}$. Station has given a range of $5.9 \%$ to $6.8 \%$. Protein content was found to be $5.5 \%$. The highest yield ever recorded at the H. Station was that of ewe No. 1725 which in her 2nd lactation produced $597.4 \mathrm{~kg}$ of milk in 272 days (6).

\section{Genetic parameters of milk yield}

The repeatability of milk production based on earlier Island data was found to be 0.40 . The calculations were based on 4082 records (with 3.186 average number of lactations) adjusted for year, age and month of lambing, with analysis within areas (38). Initial calculations of heritability of milk production from the Island have given the values of $0.74 \pm 0.34$, $0.31 \pm 0.15$ and $0.40 \pm 0.12$, respectively for the first, second and third and more lactations (38). Recently estimated heritability values from Cyprus were for first lactation: $0.29 \pm 14$, 90-day milk production: $0.30 \pm 13$ and total MY after weaning: $0.39 \pm 0.14$. Part and total lactation yields were highly and positively correlated genetically $(0.98 \pm 0.08)(26)$. Currently, estimates of genetic parameters from the H. Station data are under processing.

\section{Observations on udder characteristics and mechanical milking}

Problems associated with mechanical milking are under study at the H. Station and in Cyprus. The udder of Chios sheep is large but

Table 5. Frequency distribution of annual milk production.

\begin{tabular}{lrrrr}
\hline $\begin{array}{l}\text { Classe } \\
\text { Kg }\end{array}$ & \multicolumn{2}{c}{$\begin{array}{c}1957-62 \\
\text { Island }\end{array}$} & \multicolumn{2}{c}{\begin{tabular}{c} 
H. Station \\
\hline
\end{tabular}} \\
\hline & $\mathrm{N}$ & $\%$ & $\mathrm{~N}$ & $\%$ \\
$20-99$ & 629 & 12.6 & 215 & 10.4 \\
$100-199$ & 2721 & 54.6 & 914 & 44.3 \\
$200-299$ & 1389 & 27.9 & 684 & 33.1 \\
$300-399$ & 229 & 4.6 & 214 & 10.4 \\
$400-499$ & 14 & 0.3 & 37 & 1.8 \\
\hline
\end{tabular}


its conformation has certain weaknesses, such as pendulous shape and high inclination of teats. This latter character is assumed responsible for many problems during mechanical milking, e.g. drop of teat cups and inhibition of the let down reflex (18). According to calculations in Cyprus, simple correlation coefficients between 90-day milk production and udder length, and between udder circumference and distance between teats at 3 or 92 day post partum ranged from 0.50 to 0.79 (34). The fractions of milk obtained by mechanical means in first lactation ewes at the H. Station were $60 \%$ by machine milking, $28.5 \%$ by machine stripping and $11.5 \%$ by hand stripping (14). Research in progress indicates that omitting one or two Sunday milkings has no significant effect on milk quantity and quality (13).

\section{Body weight, growth and carcass characteristics}

In Turkey, the height and weight of ewes were found $65-75 \mathrm{~cm}$ and $40-45 \mathrm{~kg}$, respectively. In the case of Boztepe and Cesme farms the height and weight were found $73 \mathrm{~cm}$ and $52 \mathrm{~kg}$, respectively (32). In the Chios island, height and weight of ewes were $70-76 \mathrm{~cm}$ and $48-52 \mathrm{~kg}$ and those of rams $81 \mathrm{~cm}$ and $65-$ $80 \mathrm{~kg}(19,21)$. Higher figures are given by experimental flocks in Cyprus with ewe weights ranging from $55 \mathrm{~kg} 5$ weeks post partum to $57 \mathrm{~kg}$ at lambing (23). H. Station corresponding measurements were on the average $75 \mathrm{~cm}$ and $70 \mathrm{~kg}$ for ewes and $84 \mathrm{~cm}$ and $89.5 \mathrm{~kg}$ for rams (6). The semi-fat-tailed characteristic has been regarded as a disadvantage. From various measurements in the Island the length of the tail was found $24-27 \mathrm{~cm}$ and its breadth at the base $9-12 \mathrm{~cm}$. Studies in Athens with 38 female lambs, slaughtered at $40 \mathrm{~kg}$ body weight, showed that docking at birth caused a statistically significant increase in the weight of the epiploon and the percentage of body fat (33).

Calculations in Cyprus on 1632 lambs of both sexes have given weights $(\mathrm{kg}) 3.8 \pm 0.03$ at birth, $14.8 \pm 0.11$ at weaning (45-day) and $27.3 \pm 0.2$ at 105 days. The post weaning growth rate was $218 \pm 3 \mathrm{~g} /$ day (29). Heritabilities were found for birth weight: $0.13-$ 0.16 , weaning weight: $0.36-0.47$ (the lower limit is referring to female lambs), 5 weeks: $0.34,10$ weeks: $0.63,15$ weeks: $0.73,20$ weeks: 0.66 and average daily gain (birth to weaning): $0.35(26,25)$. Comparable results on growth obtained at the H. Station with body weight of 1058 male and 1186 female lambs from birth to 6 months of age, are shown in Table 6. Daily growth rate during suckling was found $282 \mathrm{~g}$ and $216 \mathrm{~g}$ for male and female lambs, respectively (6). Carcass studies in Cyprus at fixed age, gave cold carcass weight and dressing percentage of male lambs at 42 days: $7.46 \mathrm{~kg}$ and $47.7 \%$ and at 60 days: $9.12 \mathrm{~kg}$ and $47.4 \%$, respectively. The ratio milk/carcass gain was found for single males: 8.49 and for twins: 8.71. Regression equations predicting carcass weight from live weight were also computed (3). Similar research being done with fixed slaughter weight, in addition to dressing percentages, gave the following data concerning carcass composition of the join "best and neck» at $18 \mathrm{~kg}$ slaughter weight: lean $=47.55 \%$, fat $=$ $31.42 \%$ and bones + tendons $=21.03 \%(15)$. At the H. Station, the composition of the joints rack and loin was found by dissection to be: lean $=59.5 \%$, fat $=21.1 \%$ and bones $=19.4 \%(20)$.

\section{Crossbreeding}

Crossbreeding between different local Greek breeds and $\mathrm{C}$ for upgrading purposes has been used lately to a considerable extent, but often without being part of a well planned and controlled scheme. As a consequence, the results have not been always satisfactory, especially in instances that the crossbred animals are exploited under very extensive and marginal conditions. In Cyprus, $\mathrm{C}$ rams have been used more systematically for upgrading the local Cyprus fat-tailed breed, with result the creation of a crossbred population of 115000 
head, with $5 / 8 \mathrm{C}$ and $3 / 8$ local blood. $\mathrm{C}$ was also crossed on a smaller scale with Awassi (A) and East Friesian (EF) (30).

Experimental upgrading in Greece with EF rams showed that $F 1$ ewes had the best productivity for milk yield, prolificacy and lamb viability. However, 3/4 EF crossbreds were inferior to $\mathrm{C}$ ewes, as it appears from $\mathrm{Ta}$ ble $7(39,16)$. Lambs from industrial crossbreeding between $\mathrm{C}$ and several indigenous Greek breeds were heavier than purebreds at birth and at 90-100 days of age (7). Loin composition of crossbred lambs $\mathrm{EF} \times \mathrm{C}$ was found to be: lean $=68.36 \%$, fat $=20.78 \%$ and bones $=10.86 \%$ at $30 \mathrm{~kg}$ slaughter weight and lean $=64.14 \%$, fat $=26.31 \%$ and bones $=$ $9.55 \%$ at $38 \mathrm{~kg}$ slaughter weight (17). In Cyprus, $\mathrm{A} \times \mathrm{C}$ crossbreds outyielded purebreds and other crossbreds in milk, fat and protein (24). Crossing $\mathrm{C}$ with local and Awassi resulted in 20-week heavier lambs in comparison to those of the aforementioned pure breeds (22). A more recent trial, $\mathrm{C} \times \mathrm{A}$ resulted in heavier lambs $(\mathrm{kg})$ at birth $(\mathrm{C}=3.8, \mathrm{~A}=4.1, \mathrm{C} \times \mathrm{A}=$ 4.4), weaning $(C=14.8, A=16.0, C \times A=$ 17.0) and 105-day $(C=27.3, A=28.1, C \times A=$ 29.6). Traits studied exhibited the highest heterosis for weaning weight $(7.5 \%)$ and the lowest for birth weight $(6.3 \%)$ (29). Crossbreeding between $\mathrm{C}$ and $\mathrm{A}$ in Turkey aimed at investigating the possibilities of producing fast growing and high carcass quality slaughter lambs $(9,10,11)$. Similar crossbreeding trials are also reported from Lebanon between $\mathrm{C}$ and A (4) and from the Sultanate of Oman between $\mathrm{C}$ and $\mathrm{A}(5)$ and more recently between $\mathrm{C}$ and the Omani breed (36).

\section{General considerations}

C constitutes a highly valuable genetic material, contributing considerably to the increase of milk and lamb productivity under relatively improved husbandry conditions. Experiences so far acquired from the place of origin and the neighbouring areas of Greece, Turkey and Cyprus suggest that this breed can
Table 6. Body weight of lambs (Halkidiki Station).

\begin{tabular}{|c|c|c|c|c|c|c|}
\hline & \multicolumn{3}{|c|}{$\mathrm{males}$} & \multicolumn{3}{|c|}{ f e males } \\
\hline & $\mathrm{n}$ & $\overline{\mathrm{x}}$ & s & $\mathrm{n}$ & $\bar{x}$ & s \\
\hline Birth & 327 & 3.78 & 0.91 & 313 & 3.53 & 0.79 \\
\hline 42 days & & & & & & \\
\hline (weaning) & 299 & 15.61 & 2.94 & 297 & 13.32 & 2.22 \\
\hline 60 days & 108 & 21.65 & 3.07 & 145 & 17.34 & 2.72 \\
\hline 90 days & 108 & 29.42 & 3.77 & 145 & 23.08 & 2.79 \\
\hline 5 months & 108 & 44.34 & 4.70 & 143 & 34.51 & 3.31 \\
\hline 6 months & 108 & 51.02 & 5.20 & 143 & 37.40 & 3.85 \\
\hline
\end{tabular}

Table 7. Crossbreeding Chios $\times$ East Friesian ( 8 ).

\begin{tabular}{lcccc}
\hline Trait & \multicolumn{4}{c}{ G e n o t y p e } \\
\cline { 2 - 5 } & Chios & Friesian & $F_{1}$ & $\begin{array}{c}3 / 4 \\
\text { Friesian }\end{array}$ \\
\hline $\begin{array}{l}\text { Milk (Kg) } \\
-\begin{array}{l}\text { Suckling } \\
\text { (56 days, twins) }\end{array}\end{array}$ & 98 & 100 & 103 & 97 \\
$-\begin{array}{l}\text { Milking } \\
\quad(190 \text { days) }\end{array}$ & 180 & 165 & 202 & 171 \\
$\quad$ Total & 278 & 265 & 305 & 268 \\
$\begin{array}{l}\text { Prolificacy } \\
\text { Lamb mortality }\end{array}$ & 1.80 & 1.68 & 1.87 & 1.52 \\
before weaning $\%$ & 1.24 & 8.40 & 2.95 & 3.45 \\
\hline
\end{tabular}

be raised successfully in a quite wide range of ecological conditions within the broader Mediterranean xyrothermic context. In any event, $\mathrm{C}$ is not recommended for replacing or upgrading hardy native sheep when prevailing raising conditions are adverse and difficult. Efforts, for example, to raise Sakiz sheep in central Turkey under dry and cold climate resulted in decline of milk yield and fertility (35). Indications in Greece also suggest that $\mathrm{C}$ sheep suffer a drop in production when exposed to cold and windy conditions.

In Cyprus there are three important conditions favoring the development of the breed: (a) a substantially large population, (b) the necessary structure (70 \% of units have over 20 animals), which permits the application of new management systems and (c) a genetic improvement programme under development. This latter programme is meant to have a pyramidal scheme, at the base of which are pri- 
vate production farms (70000 sheep) and at the top will operate state breeding stations and private selection units (10\% of the base) (30). Currently, due to its large $\mathrm{C}$ population size, Cyprus represents the main exporter of breeding stock to Near East and North African countries (30).

In Greece, until the sixties raising of pure C sheep was practically limited to the island itself. Since then, however, its exploitation was extended to the Greek mainland, with the installation of medium size units, kept under more or less intensive conditions. It should not be overlooked, however, that uncontrolled crossbreeding of mainland breeds with $\mathrm{C}$ rams with natural service and artificial insemination have preceded pure breeding operations and in many cases have caused problems. The Island nucleus is recently decreasing in size, but without immediate danger of extinction given that the breed is well established in the Greek mainland, in Cyprus and in Turkey: This shrinking is mainly due to the gradual diminution of interest of younger people for this kind of small family enterprise, the size of which creates by itself problems in adapting modern husbandry techniques. Other factors contributing to this unfavourable evolution are the absence of a vigorous breeding and promotion organisation (rigid selection, lamb marketing etc.), the lack of locally produced feedstuffs and the tendency to replace sheep by dairy goat raising. To cope with this among the measures taken are subsidies of 1750, 2100 and 2500 drach. for every controlled ewe for the first, second and third year, respectively, and of 4000-7000 drach. for every purchase of young rams (21). The European Communities, on the other hand, provide economic support for the establishment of new units. It is the general conviction that the insular nucleus (the purity of which is in some degree guaranteed by the geographical isolation), should be strengthened and reconstituted to a population size of at least $4000-5000$ head in order to preserve the original gene pool. This will permit again the possibility to provide genetic material to the rest of Greece and to various countries as it had been done until 1980 (21). This can be accomplished by changing the exploitation system from traditional stall-fed of $1-10$ head to a more enterprising type of $20-30$ head, where the substantial economic and technical assistance will be readily applicable. Under such circumstances, the implementation of sound control networks for systematic selection will become possible (tentatively, a progeny testing scheme) and the establishment of the flockbook and the necessary association for the promotion of the breed will become reality. With reference to the mainland sector, it is suggested that a nationwide breeding plan should be adapted which will include identification of purebred animals and technical control of breeding stock, and in a more advanced stage application of a genetic improvement scheme in close connection to the one in the island of Chios. Besides being used for animal improvement in Greece, it would have been interesting to exploit more thoroughly the prolific value of this rare genetic resource in crossbreeding schemes with foreign breeds, with immediate objective to increase lamb meat production in the broader Mediterranean area.

As it becomes obvious from the above, the valuable $\mathrm{C}$ breed, combining high dairy and prolific properties, if given zootechnical support and correctly exploited, has the genetic potential to contribute substantially to the amélioration of sheep productivity in the region under consideration.

\section{References}

1. Avdi, M., Vergos, V., Alifakiotis, T., Michailidis, I., Driancourt, M.A. \& Chemineau, P., 1988. Seasonal variations of oestrous behaviour and ovula-

tion rate in Chios and Serres ewes in Greece. Proc. 3rd World Congr. Sheep Beef Cattle Breed. Paris, 2: $647-649$. 
2. Dórgunes, O., Elıı̨in, A., Sönmez, R. \& B.C. YALçıN, 1983. Genetic improvement of sheep in Turkey. Proc. Inter. Symp. Prod. Sheep and Goats Mediterr. Area. E.A.A.P., Ankara.

3. ECONOMIdES, S., 1984. The effect of lamb-weaning age on the milk yield of Chios ewes and the growth and carcass gain of lambs. Agric. Res. Inst. Cyprus, Techn. Bull. No. 59.

4. Fox, C., Chaaban, R., Hardison, W., Badawi, S., Choueirı, E., \& M. MaAlouf, 1971. Selection and Breeding programs of Awassi and Chios sheep. Inst. Rech. Agron., Liban, Publ. No. 36.

5. Fox, C., Choueiri, E. \& R. ChaAban, 1976. The results of crossbreeding between Chios and the local fat-tail Awassi. 27th Ann. Meet. EAAP, Zürich, Switzerland.

6. Gabrilidis, G.H., 1988. Personal communication.

7. Gabrilidis, G.T., 1988. Personal communication.

8. Genetic Improvement Center of Thessaloniki, 1988.

9. Guney, O. \& L. OzCan, 1982. The fattening performance and carcass characteristics of Awassi $\times$ Awassi and Chios $\times$ Awassi $\left(F_{1}\right)$ ram lambs. Univer. Cukurova, Spec. Ed., year 13, No 3-4.

10. Guney, O. \& L. OzCan, 1983. Crossbreeding to increase meat production of the native Awassi sheep. Univ. Cukurova, Spec. Ed., year 14, No 1.

11. GONEY, O. \& O. BICER, 1986. The fattening performance and carcass characteristics of Awassi $\times$ Awassi, Ile de France $\times$ Awassi $\left(F_{1}\right)$ and Chios $\times$ Awassi first back cross $\left(B_{1}\right)$ ram lambs. World Rev. Anim. Prod. Vol. XXII, No 1.

12. Hatziminaoglou, I., Zervas, N. \& Boyazoglu, J.G., 1985. Sheep and Goats in Greece. (Spec. Ed. Univ, of Thessaloniki).

13. Hatziminaoglou, I., 1987. Effect of omitting one or two Sunday milkings on milk quantity and quality of Chios breed. Epitheorissi Zootechnikis Epistimis (Animal Science Review). Spec. Ed. No 3: 45-46.

14. Hatziminaoglou, I., T. Papadopoulos, A. GeorGoudis \& I. Michailidis, 1987. Characteristics of machine milking of first lactation Chios and Kimi ewes. Epitheorissi Zootechnikis Epistimis (Animal Science Review), No 6.

15. Hatzipanayiotou, M., Georghiades, E. \& G.M. DEKKER, 1986. Growth and carcass characteristics of milk-fed Chios lambs slaughtered at different body weights. Agric. Res. Inst. Cyprus, Techn. Bull. No 80 .

16. Kalaissakis, P., Papadimitriou, T., Flamant, J.C., Boyazoglu, J.G. \& N. Zervas, 1977. Comparaison des races ovines Chios et Frisonne avec leurs croisements en Grèce continentale. II. Production laitière. Ann. Génét. Sél. anim. 9 (2), 181-201.

17. Kyriafinis, B., Kalaissakis, P., Zervas, N., Papadopoulos, G. \& Hatziminaoglou, J., 1974. Contribution to the study of fattening weaned crossbred Friesian $\times$ Chios and Friesian $\times$ Serrai lambs. (in Greek), Geoponika, 219: 175-185.

18. LABUSSIÉrE, J., 1985. Facteurs physiologiques et anatomiques influençant l'aptitude à la traite des brebis. Conséquences pour l'organisation du traival des trayeurs. 36th Ann. Meet. EAAP, Halkidiki, Greece.

19. MAson, I.L., 1967. Sheep breeds of the Mediterranean. Farnham Royal, England. Commonwealth Agricultural Bureaux, F.A.O.

20. Matsoukas, I., Papadopoulos, T., Gabrilidis, G.H. \& Karalazos, A., 1988. Unpublished data.

21. Ministry of Agriculture of Greece, 1988. Control data from the Agricultural Service of Chios.

22. Mavrogenis, A.P. \& A. Louca, 1979. A note on some factors influencing postweaning performance of purebred and crossbred lambs. Anim. Prod. 29: 415-418.

23. Mavrogenis, A.P., J. Hancock \& A. Louca, 1980. The effect of body weight changes during pregnancy and lactation on the performance of three breeds of sheep. J. Agric. Sci., Camb. 95: 357-363.

24. Mavrogenis, A.P. \& A. Louca, 1980. Effects of different husbandry systems on milk production of purebred and crossbred sheep. Anim. Prod. 31: $171-176$.

25. Mavrogenis, A.P., Louca, A. \& O.W. Robison, 1980. Estimates of genetic parameters for pre-weaning and post-weaning growth traits of Chios.lambs. Anim. Prod. 30: 271-276.

26. Mavrogenis, A.P., 1982. Environmental and genetic factors influencing milk production and lamb output of Chios sheep. Livest. Prod. Sci. 8: 519-527.

27. Mavrogenis, A.P., 1985. Frequency of milk recording and utilization of part lactation records for selection in Chios sheep. Agric. Res. Inst. Cyprus, Techn. Bull. No. 64.

28. Mavrogenis, A.P., 1985. The fecundity of the Chios sheep. In Genetics of Reproduction in Sheep. (Eds. R.B. LAND \& D.W. RoBinson) London, U.K., Butterworths; 63-67.

29. Mavrogenis, A.P. \& A. Constantinou, 1986. Performance evaluation of purebred and crossbred lambs. Agric. Res. Inst., Cyprus, Techn. Bull. No. 77.

30. Mavrogenis, A.P., 1988. Personal communication.

31. Michailidis, I., 1985. Reproductive parameters of the Chios and Kimi breeds. Doct. Thesis. Univ. of Thessaloniki (in Greek).

32. Özcan, H., 1965. Publ. No. 177 of the Veter. Fac. Ankara Univ. (in Turkish).

33. Panopoulou, E., T. Papadimitriou, S. Deligiannis \& E. RoGdakis, 1987. Effect of docking Chios sheep on the redistribution of body fat, the size of fattycells and the activity of NADP-enzymes in different fatty-tissues. Epitheorissi Zootechnikis Epistimis (Animal Science Review). Spec. Ed. No. 3. 
34. Papachristoforou, C. \& A.P. Mavrogenis, 1981. Udder characteristics of Chios sheep and their relation to milk production and machine milking. Agric. Res. Inst. Cyprus, Techn. Paper No. 20.

35. Sónmez, R., 1962. Breed characters and different productions in the Sakiz sheep (Chios Schafe) of Turkey. Z. Tierz. Zücht.biol. 78: 281-286.

36. Steel, M., 1983. Initial results of sheep cross-breeding programme: Chios $\times$ Omani. Univ. Durham. Vol. IB, Number 4.

37. YaLçIN, B.C., 1979. The sheep breeds of Afghan- istan, Iran and Turkey. F.A.O., Rome.

38. Zervas, N.P., 1965. Contribution to the phenotypic and genetic study of dairy production of the Chios breed (in Greek). Diss. Agric. School of Athens, Greece.

39. Zervas, N., Boyazoglu, J.G., Kalaíssakis, P., Papadimitriou, T. \& J.C. Flamant, 1975. Comparaison des races ovines Chios et Frisonne avec leurs croisements en Grèce continentale. I. Viabilité et reproduction. Ann. Génét. Sél. anim. 7 (3): 277291. 